\title{
Survey on the Perception, Needs, and Experience of Literacy Assessment and Intervention of Korean Speech-Language Pathologists
}

\author{
Hyun-Rin Park ${ }^{\mathrm{a}}$, Kyung Hee Jung ${ }^{\mathrm{b}}$, Soyeong Pae ${ }^{\mathrm{c}}$, Hyojin Yoon ${ }^{\mathrm{d}}$ \\ ${ }^{a}$ Department of Speech-Language Therapy, College of Health \& Welfare \& Education, Gwangju University, Gwangju, Korea \\ ${ }^{b}$ Department of Speech and Language Pathology, Graduate School of Rehabilitation and Welfare, Yongin University, Yongin, Korea \\ 'Division of Speech Pathology and Audiology, Hallym University, Chuncheon, Korea \\ ${ }^{d}$ Department of Speech-Language Pathology, Chosun University, Gwangju, Korea
}

\author{
Correspondence: Kyung Hee Jung, PhD \\ Department of Speech Language Rehabilitation, \\ Yongin University, 134 Yongindaehak-ro, \\ Cheoin-gu, Yongin 17092, Korea \\ Tel: +82-31-8020-2864 \\ Fax: +82-31-8020-3075 \\ E-mail: 1012jkh@hanmail.net
}

Received: April 19, 2019

Revised: May 10, 2019

Accepted: May 28, 2019

This work was supported by funding for the Accreditation Project of the Korean Association of Speech-Language Pathologists (KSLP) in 2018.

\begin{abstract}
Objectives: This survey study focused on speech-language pathologists'(SLPs) knowledge, perception, needs, and experience regarding literacy assessment and intervention. Methods: Among SLPs registered in the Korean Association of Speech-Language Pathologists (KSLP), 757 SLPs participated in this survey. The survey consisted of the respondents' background information; knowledge of and educational background in literacy assessment and intervention; perception of the need for literacy assessment and intervention, along with the requirement for relevant training; and experiences with literacy assessment and intervention. Results: Only $40 \%$ of the respondents reported that they have adequate expertise in literacy assessment and intervention, although about $90 \%$ realized the importance of literacy as SLPs. Over $90 \%$ of the respondents were willing to participate in relevant training programs. Even though most SLPs had encountered clinical cases requiring literacy assessment and intervention, only $64 \%$ of these cases received literacy assessments. Moreover, SLPs perceived they had a higher level of knowledge about literacy if they had more academic degrees, longer careers, had taken more classes regarding literacy, and more experience in the area of literacy. It is also noteworthy that most of them (95\%-98\%) responded indicating a willingness to participate in continuing education on literacy regardless of the aforementioned factors (i.e., academic credentials, career, former education, and clinical experience). These findings indicate a high demand for literacy-related training for SLPs. Conclusion: From this study there seems to be an urgent need to develop and implement comprehensive training programs covering issues such as literacy related education and other systematic improvements for SLPs.
\end{abstract}

Keywords: Literacy assessment, Literacy intervention, Speech-language pathologist
문해 능력은 외부 환경으로부터 정보를 습득하고 활용하기 위한 핵심적인 기술이며, 언어 발달과 학습의 가장 기초적인 기술이라 할 수 있다(Craig, Connor, \& Washington, 2003; Hallahan, Lloyd, Kauffman, Weiss, \& Martinez, 2005). 특히 초등교육 수준에서는 학년이 올라갈수록 언어학적 지식 습득에 있어 문해 능력에 대한 중요성이 더욱 높아지는데 이는 학년이 높아질수록 더욱 많은 정 보와 지식 및 어휘를 읽기 활동을 통해 접하기 때문이다. 따라서 문
해 발달의 지연은 개인의 학습문제뿐 아니라 교육적, 사회적인 불 평등도 야기하기 때문에 최근에는 국가적 차원에서 정책 및 프로 그램을 지원하고 있으며(Korea Institute for Curriculum and Evaluation, 2014; Ministry of Education, 2013) 언어치료 분야 내에서 도 이러한 관심과 요구가 높아져 왔다.

이에 언어병리학 분야에서도 학령 전후기 아동들의 언어 발달과 함께 문해 능력 발달의 중요성에 주목해 왔으며 관련 연구 또한 활 
발히 이루어져 왔다. 현재까지 언어병리학 분야에서 보고된 문해 평가 및 중재와 관련된 연구들을 살펴보면, 읽기장애 아동의 인지 특성 연구(Chung, 2014; Kim, Yoon, \& Ahn, 2003; Pae, Kim, \& Jung, 2012; Park \& Choi, 2014), 읽기장애 아동의 읽기 및 쓰기 유 형 및 특성 분석(Choi, Kim, Yun, \& Sung, 2011; Chung, 2011; Kim \& Kang, 2010; Kim, Park, \& Kim, 2010; Lee \& Lee, 2014), 읽기 중 재 효과 검토 및 중재 프로그램 개발을 위한 연구(Ahn, 2005; Lee, 2003; Lee, Kim, \& Park, 2016), 다문화 가정 아동의 언어와 읽기 특 성 연구 등(Kang \& Hwang, 2010; Pae \& Kim, 2010; Yoo, 2013)이 보고되었다. 최근에는 언어재활사들이 문해 평가 및 중재를 위해 활용할 수 있는 표준화된 검사도구들이 개발되어 출판되는 등 (Kim et al., 2014; Pae et al., 2015), 문해 평가 및 중재에 있어 학문적 인 면에서 많은 발전이 있어 왔다. 더욱이 현장에서도 언어재활사 를 대상으로 한 문해 평가 및 중재 전문가 교육과정이 개설되어, 임 상적인 면에서 중재의 질 향상을 위한 노력이 있어 왔으며 더불어 많은 언어재활사들의 교육 요구를 확인할 수 있었다. 그러나 아직 까지 언어재활현장에서 문해 평가 및 중재와 관련한 언어재활사들 의 인식과 요구를 상세히 살펴볼 수 있는 자료가 없어, 체감적인 부 분에 의존할 수밖에 없으며 이에 대한 현황 파악을 위한 기초 연구 는 찾아보기 힘들다. 특히 문해 평가 및 중재에 있어서는 언어재활 사가 자신의 경험으로 효과가 있을 것으로 생각하는 중재방법을 통해 치료하는 등 대상자들에 대한 적절한 진단과 읽기 및 쓰기 문 제의 특성을 파악하기가 어려운 것이 현실이다.

한편, 미국언어청각협회(American Speech-Language-Hearing Association, ASHA)에서는 문해 평가 및 중재와 관련한 언어임상 가(speech-language pathologist, SLP)의 중요한 역할에 대해 언급 하며 SLP는 언어장애 아동의 문해교육에 책임이 있다고 하였다 (Katz et al., 2007; Kersting, Carr, \& Kersting, 2008). 미국언어청각 협회는 2008 학교 조사 보고서를 통해 SLP가 서비스를 제공하고 있는 사례의 $63 \%$ 가 학습장애이고 $32 \%$ 가 쓰기 및 읽기장애 아동 이라고 보고하고 있어 실질적으로 임상현장에서 SLP가 문해 중재 서비스에 깊이 관련되어 있음을 알 수 있다(ASHA, 2008). Navas, Ciboto와 Borges (2017)는 읽기 능력이 삶 전반에 미치는 영향을 고 려한다면 SLP는 초기 읽기발달 과정에 있는 아동뿐 아니라 청소년 기 이후 성인기까지도 지속적으로 중요한 역할을 한다고 강조하였 다. 또한 읽기 기술을 SLP가 가르치기 위해서는 현재보다 더욱 적 극적이고 포괄적인 접근이 필요하며, SLP에게 이들을 가르치기 위 한 가이드라인의 제시도 필요함을 언급하였다(Kamhi, Allen, \& Catts, 2001). Katz 등(2007)은 미국의 SLP들을 대상으로 대규모 조 사연구를 실시하여 문해 평가 및 중재 서비스에 대한 SLP들의 지식
과 태도를 살펴보았다. 그 결과 SLP들 중 절반가량(52\%)이 이들을 돕기 위한 전문적인 지식이 있다고 보고하였으며, $78 \%$ 이상은 문해 평가 및 중재를 위한 교육을 받고 있으며, $85 \%$ 이상은 지속적 교육 에 대한 참가 의욕이 있다고 보고하였다. 더불어 지식과 태도 수준 이 높음에도 불구하고, 실제적인 임상에서는 문해교육이 필요한 아동들에게도 이러한 중재를 제공하지 못하는 경우도 많음을 보 고하며 문해 평가 및 중재에 대한 지식과 긍정적인 태도가 실제 임 상으로 이어지게끔 하도록 하는 것이 중요하다고 언급하였다. 또한 599명의 SLP를 대상으로 읽기쓰기 장애에 대한 SLP의 교육, 지식, 신념 등에 대한 조사를 실시한 연구에서는 $60.3 \%$ 의 SLP가 매주 또 는 매일 읽기 및 쓰기장애 아동들에게 서비스를 제공한다고 하였 다(Blood, Mamett, Gordon, \& Blood, 2010). 이 연구자들은 또한 문해 평가 및 중재에 대한 교육 및 임상적 훈련이 '제한적(limited)' 이며, 스스로 문해 평가 및 중재 활동에 대한 자신감은 전체적으로 '다소자신있음(somewhat confidence)'이라고 보고하였다.

국내에서도 많지는 않으나 언어재활사를 대상으로 문해 평가 및 중재에 대한 인식과 관련하여 살펴본 연구를 찾아볼 수 있다. Lee (2014)는 자폐스펙트럼장애 아동의 읽기 중재 실태 및 이에 대한 인 식을 언어재활사를 대상으로 살펴보았는데, 읽기 중재에 대한 인식 에서는 이들을 중재하기 위한 교수 지식이 충분하지 않다고 인식 하는 언어재활사가 대부분이었으며 지식이 충분하다고 인식하는 언어재활사가 $1.3 \%$ 에 그치지 않는다는 점을 보고하였다. 또한 Lee 등(2016)은 읽기 중재 애플리케이션 개발을 위해 부모 및 언어치료 사의 요구를 살펴보았는데, 읽기 중재 콘텐츠 개발에 대한 언어재 활사의 요구도가 높다는 것과 아동의 읽기 수준에 맞는 자료 사용 과 평가, 중재에 대한 어려움이 크다는 것 또한 확인할 수 있었다. 특 히 이미 현장에 있는 언어재활사들의 경우 업무와 직접적인 관련이 있는 평가 및 중재로 연결되는 지식에 대한 교육 요구가 클 것으로 여겨진다. 언어재활사는 아니지만 언어 및 의사소통장애 학생의 담 당 교사들을 대상으로 연구한 선행연구에서는 학생들이 국어과 목을 가장 어려워하고, 학급에서 보이는 어려움은 언어이해 및 표 현이 전반적으로 늦다는 점, 그 다음으로 읽기, 쓰기 및 듣기 학습 이 어렵다는 점을 지적하였다. 같은 연구에서 학생이 언어치료를 받는 이유를 교사들에게 물었을 때 약 $19 \%$ 의 교사들이 쓰기, 읽기, 듣기 등의 학습지연 때문이라고 응답하였는데 이는 일반 교사들도 언어재활사의 전문적 업무 중 읽기 및 쓰기에 대한 지원이 포함되 는 것으로 인식하고 있다는 것을 반증해주는 결과이다(Park, 2013).

이에 국내에서도 문해 평가 및 중재와 관련된 현장 언어재활사들 의 인식과 요구, 경험의 현황을 살펴보는 기초연구를 통해 추후 언 
어재활분야의 문해 평가 및 중재와 관련된 교육의 방향성과 문해 영역에 대한 언어재활사들의 책무성 강화를 위한 기초자료 마련이 필요한 시점이다. 따라서 본 연구에서는 문해 평가 및 중재에 관한 언어재활사의 인식, 요구도 및 경험에 대한 대규모 설문조사를 통 하여 언어재활현장에서의 문해 평가 및 중재 현황과 임상적인 면에 서 어떠한 요구가 있는지와 언어재활사들이 해당 분야의 평가 및 중재에 대해 어떻게 인식하고 있는지를 살펴보고자 하였다.

\section{연구방법}

\section{연구대상}

한국언어재활사협회 회원으로 등록되어 있는 전국 8,000 여 명 의 언어재활사를 대상으로 하여 배포한 구글 설문에 응답한 757 명 (여 719명, 남 38 명)을 본 연구의 분석 대상으로 하였다. 본 연구 설 문 응답자의 기본 정보를 Table 1 에 제시하였다.

\section{설문 도구}

본 연구에서는 문해 평가 및 중재와 관련된 언어재활사들의 인 식과 요구, 경험을 살펴보기 위해 설문지를 개발하였다. 본 연구의 설문지를 개발하기 위하여 미국언어청각협회에서 발표된 문해 평 가 및 중재에 관한 언어치료사의 인식 연구와 지식 평가 연구 등 (Katz et al., 2007; Kersting et al., 2008)을 참고로 연구자 간의 수차 례 회의를 거쳐 국내의 사정에 맞춘 설문지 초안을 작성하였다.

다음으로 본 연구의 설문지 초안이 연구 목적에 적절한 문항들 을 포함하고, 언어재활사들의 의견을 수렴하는 데 적절한지를 파 악하기 위해 전문가 패널을 대상으로 타당도 조사를 실시하였다. 전문가 패널은 국내 언어치료학과에서 학습장애언어재활, 학령기 언어발달장애, 읽기장애 등의 수업을 담당하고 있는 10 인의 교수진 으로 구성되었으며, 2 차에 걸친 반복조사를 실시하였다. 1 차 조사 에서는 모든 항목에 대해 Likert 5점 척도(5점 매우 적절함, 4 점 적 절함, 3 점 보통, 2 점 적절하지 않음, 1 점 매우 적절하지 않음)를 사용 하여 질문이 타당한지 평가하고, 패널들의 의견을 개방형 질문을 통해 수렴하였다. 1 차 조사를 통해 집계된 타당도의 평균이 4.0 미 만인 항목은 삭제, 4.0 이상 4.5 미만인 항목은 수정을 거치고 의견 을 반영하여 보완 후 2 차 조사를 실시하였으며 1 차 조사 내용과 마 찬가지로 Likert 5 점 척도로 타당도 평가와 의견 수렴의 절차를 거 쳤다. 최종 설문지에 포함된 모든 문항은 전문가 패널의 평가에 의 해 타당도가 평균 4.75 이상이었다.

최종 설문지는 (1) 응답자 기본정보에 대한 문항(6문항), (2) 문해 관련 지식 및 교육 경험에 대한 문항(8문항), (3) 문해 평가 및 중재
Table 1. Basic information of participants ( $N=757)$

\begin{tabular}{|c|c|}
\hline Characteristic & Value $(\%)$ \\
\hline \multicolumn{2}{|l|}{ Gender } \\
\hline Female & 95.0 \\
\hline Male & 5.0 \\
\hline \multicolumn{2}{|l|}{ Age (yr) } \\
\hline $21-25$ & 10.7 \\
\hline $26-30$ & 29.2 \\
\hline $31-35$ & 18.1 \\
\hline $35-40$ & 16.0 \\
\hline $41-45$ & 12.2 \\
\hline $46-50$ & 8.7 \\
\hline$\geq 51$ & 5.2 \\
\hline \multicolumn{2}{|l|}{ Region of work facilities } \\
\hline Incheon/Gyeonggi-do & 25.8 \\
\hline Busan/Ulsan/Gyeongsangnam-do & 17.0 \\
\hline Seoul & 16.6 \\
\hline Daegu/Gyeongsangbuk-do & 9.0 \\
\hline Gwangju/Jeollanam-do & 8.9 \\
\hline Daejeon/Chungcheongnam-do & 8.6 \\
\hline Gangwon-do & 4.4 \\
\hline Jeollabuk-do & 3.7 \\
\hline Chungcheongbuk-do & 2.8 \\
\hline Jeju & 2.3 \\
\hline Others (Sejong, prepareing to new employment, on leave) & 0.9 \\
\hline \multicolumn{2}{|l|}{ Type of work facilities } \\
\hline Private center of language-speech therapy & 58.4 \\
\hline Welfare center & 12.9 \\
\hline Hospitals & 11.9 \\
\hline Multicultural family support center & 4.2 \\
\hline Special education support center & 3.0 \\
\hline Child-care center & 2.4 \\
\hline University & 1.4 \\
\hline Schools of special education & 0.8 \\
\hline Rehabilitation and education center for child with disability & 0.8 \\
\hline Others (Part-time in two or more facilities, on leave) & 4.2 \\
\hline \multicolumn{2}{|l|}{ Clinical career (yr) } \\
\hline$<1$ & 4.8 \\
\hline $1-3$ & 19.8 \\
\hline $3-5$ & 18.0 \\
\hline $5-10$ & 31.7 \\
\hline $10-20$ & 22.6 \\
\hline$>20$ & 3.2 \\
\hline \multicolumn{2}{|l|}{ Degree } \\
\hline Associate degree & 4.0 \\
\hline Bachelor's degree & 42.1 \\
\hline Master diploma & 9.8 \\
\hline Master's degree & 37.6 \\
\hline Doctoral diploma & 2.8 \\
\hline Doctoral degree & 3.7 \\
\hline
\end{tabular}


에 대한 필요성 인식과 교육 요구도에 대한 문항(8문항), (4) 문해 평 가 및 중재 경험과 관련된 문항(7문항)으로 구성하였다. '기본정보 에 대한 문항’에는 성별, 연령, 근무기관 소재지, 근무기관 유형, 임 상경력, 최종학력을 포함하였다. '문해 관련 지식 및 교육 경험에 대 한 문항'에는 스스로 지각하는 지식의 수준과, 문해 능력 평가 및 중재를 위해 중요하다고 생각하는 지식, 교과목 이수에 대한 현황 과 교육 및 연수에 대한 현황을 포함하였다. '문해 평가 및 중재에 대한 필요성 인식과 교육 요구도'에 대한 문항에는 문해 평가 및 중 재가 언어치료의 중요한 영역이라 생각하는지 여부, 전문가 교육의 필요 여부, 전문가 교육에서 다루기 원하는 주제를 포함하였다. '문 해 평가 및 중재 경험과 관련된 문항'에는 사례 경험 여부, 평가 경 험 여부, 평가에 사용하는 검사도구, 중재 경험 여부, 중재 대상자에 대한 정보 질문 등으로 구성되었다.

\section{자료수집 및 분석방법}

자료수집

본 설문조사의 조사 기간은 2018년 7월 11 일부터 26일까지였다. 설문은 구글 설문지로 작성되어 한국언어재활사협회 회원으로 등 록되어 있는 언어재활사에게 문자 및 메일로 설문의 URL 주소를 배포하였다. 구글 설문지에 본 연구의 목적에 대해 서술하였으며, 위 조사 기간 내 온라인으로 회수된 설문을 본 연구의 분석대상으 로 하였다.

\section{자료분석}

본 연구의 분석은 크게 문해 관련 지식 및 교육 경험, 문해 평가 및 중재에 대한 필요성 인식과 교육 요구도, 문해 평가 및 중재 경험 의 세 가지 측면에서 이루어졌다. 각각의 문항은 Likert 5 점 척도 문 항, 단일선택 문항, 중복선택 문항, 예/아니오 선택 문항 등 질문의 특성에 따라 다양하게 구성되어 있다. 자료의 분석은 각 문항의 특

Table 2. Knowledge for literacy assessment and intervention perceived by SLPS (N=757)

\begin{tabular}{lc}
\hline Items for multiple-choice questions & No. $(\%)$ \\
\hline Phonological awareness & $577(76.2)$ \\
Reading comprehension & $519(68.6)$ \\
Letter knowledge and orthographic knowledge & $339(44.8)$ \\
Reading fluency & $287(37.9)$ \\
Vocabulary & $176(23.2)$ \\
Spelling & $153(20.2)$ \\
Word recognition & $146(19.3)$ \\
Sentence writing & $69(9.1)$ \\
\hline
\end{tabular}

$\mathrm{SLP}=$ speech-language pathologist
성에 따라 빈도 분석을 실시하였으며 IBM SPSS Statistics version 20으로 각 문항 응답의 빈도수 및 백분율을 산출하였다.

\section{연구결과}

\section{문해 관련 지식 및 교육 경험에 대한 결과} 언어재활사로서 지각하는 문해능력 평가 및 중재를 하기 위한 전문적 지식 여부

언어재활사로서 문해 능력 평가 및 중재를 하기 위한 전문적 지 식이 있다고 생각하는지 Likert 5점 척도(매우 그렇지 않다 1점, 그 렇지 않다 2점, 보통이다 3점, 그렇다 4점, 매우 그렇다 5점)로 응답 하도록 하였다. 응답 결과, 매우 그렇지 않다 $3.3 \%$ (25명), 그렇지 않 다 $18.5 \%$ ( 140 명), 보통이다 $37.6 \%$ (285명), 그렇다 $31.7 \%$ ( 240 명), 매 우 그렇다 $8.9 \%$ (67명)로 문해 능력 평가 및 중재를 위해 언어재활 사로서 전문적 지식이 있다고 생각하는 비율(그렇다, 매우 그렇다) 은 전체의 $40.6 \%$ 인 것을 알 수 있었다.

\section{문해 평가 및 중재를 위해 중요하다고 생각하는 지식}

문해능력 평가 및 중재를 위해 중요하다고 생각하는 지식(중복 선택 가능)에 대해서는 음운인식 $76.2 \%$ (577명), 읽기이해 $68.6 \%$ (519명), 자모지식과 글자지식 $44.8 \%$ (339명), 읽기 유창성 $37.9 \%$ (287명), 어휘 $23.2 \%$ (176명), 철자쓰기 20.2\% (153명), 단어수준의 읽기 $19.3 \%$ (146명), 작문쓰기 9.1\% (69명) 순으로 나타났다. 응답에 대한 결과를 Table 2에 제시하였다.

\section{대학 및 대학원에서의 관련 교과목 이수 여부}

대학 및 대학원 등 교육기관에서 문해 평가 및 중재에 관한 교과 목 이수 여부에 대해서는 전체의 $54.3 \%$ (411명)가 ‘네(이수)', $45.7 \%$ (346명)가 ‘아니오(미이수)’로 응답하였다(Table 3).

대학 및 대학원에서 관련 교과목을 이수한('네’로 응답) 언어재 활사들에 한하여 '대학 및 대학원에서 문해 평가 및 중재를 위해 이 수한 수업의 교과목(중복선택 가능)이 무엇인가'를 묻는 추가질문 에는 학령기 언어발달(의사소통)장애(66.4\%), 학습장애언어재활

Table 3. Experience of literacy related education as major courses within the curriculum at as non-formal education/workshop ( $\mathrm{N}=757)$

\begin{tabular}{lcc}
\hline Related education & Yes & No \\
\hline $\begin{array}{l}\text { Major courses within the curriculum at university } \\
\text { and graduate schools }\end{array}$ & $411(54.3)$ & $346(45.7)$ \\
Non-formal education or workshop & $401(53.0)$ & $356(47.0)$ \\
\hline
\end{tabular}

Values are presented as number (\%). 
(39.6\%), 읽기장애(35\%) 순으로 응답하였으며, 개별 응답자(학습장 애, 학습장애아교육, 언어학 등)는 $2 \%$ (10명)에 불과하였다.

반면에 대학 및 대학원에서 관련 교과목을 이수하지 않은(이수 에 ‘아니오'로 대답한) 언어재활사들에 한하여 '대학 및 대학원에서 해당 교과목을 이수하지 않은 경우, 가장 큰 이유는 무엇인가'를 묻 는 추가질문에서 가장 큰 비율을 차지한 답변은 개설이 되지 않아 서(86.8\%)가 대부분이었으며, 개설이 되었으나 교과목의 중요성을 인지하지 못해서(7.9\%), 개설이 되었으나 나의 임상(평가 및 중재) 에 도움이 될 것 같지 않아서(2\%), 개설이 되었으나 이미 알고 있는 내용들만 다루어서(1\%) 순으로 응답하였다.

대학 및 대학원의 정규 교과목 외 문해 평가 및 중재와 관련한 교육 및 연수 경험 여부

대학 및 대학원 정규 교과목 외에 문해 평가 및 중재와 관련하여 어떤 형식이든 교육 및 연수 경험 여부에 대해서는 전체의 $53 \%$ (401 명)가 ‘있다’, $47 \%$ (356명)가 ‘없다’로 응답하였다(Table 3).

교육 및 연수를 받은 적이 있는 언어재활사들에 한하여 ‘교육 및 연수회를 어떤 방식으로 접하였는가'를 묻는 추가질문에는 언어재 활사 보수교육이 가장 많은 비율(55.3\%)을 차지하였고, 별도의 자 격/수료증 과정 이수와 대학 및 대학원 등 교육기관에서의 특강 형 태가 각각 $31.9 \%, 31.4 \%$ 로 비슷한 비율이었다. 그 외 $(2.5 \%, 12$ 명)의 개별 응답으로는 다문화 언어발달 지도사 보수교육, 사설기관 연 수, 개별적인 치료실 스터디, 학회의 교육 등을 통해 접한 경우가 포 함되어 있었다.

반면에 교육 및 연수를 받은 적이 없다고 응답한 언어재활사들 에 한하여 '문해 평가 및 중재를 위한 교육 및 연수를 받은 적이 없 을 경우, 가장 큰 이유를 묻는 추가질문에서는 정보 및 기회를 접한 적이 없어서 $(56.8 \%)$ 가 가장 많았으며, 참여하고자 하였으나 너무 멀어서(19.7\%), 참여하고자 하였으나 교육비의 문제로(10.6\%), 현재 치료하는 대상자의 평가 및 치료에 도움이 될 것 같지 않아서 (5.5\%), 정보 및 기회를 접하였으나 이미 알고 있는 내용들을 다룰 것이라 생각해서(3.4\%) 순으로 응답하였다. 그 외 $2 \%$ 가량의 개별 응답자들의 경우, 근무시간과 겹쳐서 참여하지 못하였다는 의견이 대부분이었다.

\section{문해 평가 및 중재에 대한 필요성 인식과 교육 요구도에 대한 결과}

문해 평가 및 중재가 언어치료의 중요한 영역이라 생각하는지 여부

문해 평가 및 중재는 언어치료의 중요한 영역이라 생각하는지 Likert 5점 척도(매우 그렇지 않다 1점, 그렇지 않다 2점, 보통이다 3
점, 그렇다 4 점, 매우 그렇다 5 점)로 응답하도록 하였다. 응답 결과, 매우 그렇지 않다 $0.1 \%$ (1명), 그렇지 않다 $1.3 \%$ (10명), 보통이다 $9.6 \%$ (73명), 그렇다 $33.9 \%$ (257명), 매우 그렇다 55\% (416명)로 문해 능력 평가 및 중재가 언어치료의 중요한 영역이라 생각하는 비율 (그렇다, 매우 그렇다)은 전체의 $88.9 \%$ 인 것을 알 수 있었다.

\section{문해 평가 및 중재와 관련한 언어재활사 교육에 대한 요구도}

문해 평가 및 중재와 관련하여 언어재활사 교육이 필요하다고 생 각하는지를 묻는 문항에서는 ‘네’로 응답한 비율이 98.7\% (747명), ‘아니오’로 응답한 비율이 $1.3 \%$ (10명)로 대부분의 언어재활사가 문 해 평가 및 중재와 관련된 교육이 필요하다고 느끼고 있다는 것을 알수 있었다.

교육이 필요하다고 생각하는 언어재활사들에 한하여 '어떠한 영 역에서 교육에 대한 요구가 있는가'를 묻는 추가질문(중복선택 가 능)에서는 중재 93.2\% (696명), 진단 및 평가 $85.3 \%$ (637명), 이론적 기초 $51.5 \%$ (385명) 순으로 나타났다. 그 외 응답(약 $1 \%$ )에서는 사 례 관찰, 보고서 작성, 중재 자료에 대한 소개, 슈퍼비전 등의 의견 을 기입하였다.

\section{문해 평가 및 중재와 관련한 언어재활사 교육 참여 희망 여부}

문해 평가 및 중재와 관련된 전문가 교육이 있다면 참여하기 원 하는지 Likert 5점 척도(매우 그렇지 않다 1점, 그렇지 않다 2점, 보 통이다 3점, 그렇다 4점, 매우 그렇다 5점)로 응답하도록 하였다. 응 답 결과, 매우 그렇지 않다 $0.3 \%$ (2명), 그렇지 않다 $1.1 \%$ (8명), 보통 이다 $7.5 \%$ (57명), 그렇다 $28.3 \%$ (214명), 매우 그렇다 62.9\% (476명) 로 실제 교육 참여를 희망하는 언어재활사(그렇다, 매우 그렇다)가 전체의 $91.2 \%$ 인 것을 알 수 있었다.

한편, 전문가 교육 참여를 희망하는 언어재활사('그렇다', '매우 그렇다'에 응답)에 한하여 '전문가 교육에 참여할 의사가 있는 경우 가장 큰 이유는 무엇인가'를 묻는 추가질문의 응답은 내가 치료하 는 대상자의 평가 및 치료에 도움이 될 것이므로 $61 \%$ (416명), 언어 재활사로서의 전문적인 지식 향상에 도움이 될 것이므로 $38.3 \%$ (261명), 나의 급여 상승에 도움이 될 것이므로 $0.3 \%$ (2명), 나의 취 업 및 이직에 도움이 될 것이므로 $0.3 \%$ (2명) 순으로 나타났다.

\section{문해 평가 및 중재와 관련된 교육에서 다루기 원하는 주제}

문해 평가 및 중재와 관련된 전문가 교육에서 다루기 원하는 주 제가 무엇인지를 묻는 문항(중복 가능)에서는 Table 4에 제시한 바 와 같은 결과를 얻었다. 결과를 살펴보면 문해 능력 평가의 실시 및 해석 76.5\% (579명), 치료의 실제와 임상사례 슈퍼비전 70.9\% (537 
Table 4. Education contents that SLPs are willing to learn

\begin{tabular}{lc}
\hline Items for multiple-choice questions & No. (\%) \\
\hline Comprehension and interpretation of literacy assessment results & $579(76.5)$ \\
Practice of intervention and expert's supervision & $537(70.9)$ \\
Goal-setting for intervention & $465(61.4)$ \\
Application of teaching materials and tools & $420(55.5)$ \\
Basic theory in literacy & $298(39.4)$ \\
\hline
\end{tabular}

명), 치료 목표 설정 $61.4 \%$ (465명), 교재-교구 및 매체 활용 $55.5 \%$ (420)명, 문해교육의 이론적 기초 $39.4 \%$ (298명) 순으로 교육에 대 한 요구가 많은 것을 알 수 있었다.

\section{언어재활사의 문해 평가 및 중재에 관한 전문성을 높이기 위한 방법}

문해 평가 및 중재에 관한 언어재활사의 전문성을 높이기 위해 필요하다고 생각하는 방법은 무엇인지를 묻는 문항(중복 가능)에 서는 가장 많은 언어재활사가 '재활사 보수교육에서 관련 교육을 제공받는다(75.2\%)' 항목에 응답하였다. 다음으로 '대학 및 대학원 에서 관련 이수과목을 이수한다' $61 \%$ (462명), ‘별도의 자격과정을 이수하여 전문성을 키운다' $40.2 \%$ (304명), '대학 및 대학원에서 개 설되는 문해 관련 교과목의 수를 현재보다 늘린다' $18.5 \%$ (140명) 순으로 응답하였다.

\section{문해 평가 및 중재 경험에 대한 결과}

문해 평가 및 중재 사례에 대한 임상 경험 여부

문해 평가 및 중재가 필요한 사례를 임상현장에서 본 경험이 있 는지에 대한 질문에 대해 $83.9 \%$ (635명)가 '있다', $16.1 \%$ (122명)가 '없다'라고 응답해 다수의 언어재활사들이 임상현장에서 문해 사 례 경험이 있는 것으로 나타났다. 문해 사례 경험이 '있다'고 응답한 언어재활사를 대상으로 문해 평가가 필요한 아동을 대상으로 실제 문해 평가를 실시한 적이 있는지 여부를 묻는 질문에 대해서는 '있 다'가 $63.7 \%$ (410명), '없다'가 $36.3 \%$ (234명)가 응답하였다. 이는 약 $36 \%$ 의 아동은 문해 평가가 필요함에도 불구하고 실시되지 못하고 있음을 보여주고 있다. 반면 문해 중재를 실시하였는지 여부에 대 해서는 $80.8 \%$ (525명)가 '있다', $19.2 \%$ (125명)가 ‘없다’로 응답하여 문해 평가 및 중재가 필요한 사례를 임상 경험에서 본 경험( $83.9 \%$ 가 있다)과 유사한 비율로 보고되었다.

\section{문해 평가에 대한 경험}

문해 평가 경험이 있는 언어재활사 중 최근 1 년간 평가한 사례수 가 3명 미만인 경우가 가장 많았으며(60.4\%, 271명), 4-6명인 경우
Table 5. Literacy intervention area

\begin{tabular}{lc}
\hline Items for multiple-choice questions & No. (\%) \\
\hline Phonological awareness & $420(75.9)$ \\
Letter knowledge \& orthographic knowledge & $335(60.6)$ \\
Word recognition & $327(59.1)$ \\
Reading fluency & $309(55.9)$ \\
Reading comprehension & $343(62.0)$ \\
Spelling & $304(55.0)$ \\
Composition & $100(18.1)$ \\
\hline
\end{tabular}

$(22 \%, 99$ 명 $)$ 가 다음을 차지하였다. 한편 문해 평가가 필요함에도 평 가를 실시하지 못한 이유를 묻는 중복응답이 가능한 질문에 '진단 및 평가도구의 부재'가 $57.3 \%$ (252명)로 가장 많았고, '진단 평가방 법에 대한 지식이 부족해서'가 $46.1 \%$ (203명), '평가시간이 많이 소 요되어서'가 $28.4 \%$ (125명), '치료계획 수립 및 치료로의 연계가 부 족해서'가 $22.5 \%$ (99명)로 조사되어 문해 평가도구 및 평가지식 등 의 어려움이 가장 큰 것으로 나타났다.

\section{문해 중재에 대한 경험}

문해 중재를 실시한 경험이 있는 언어재활사들의 경우 최근 1년 간 문해 중재를 실시한 사례수는 3명 미만이 가장 많았고 $62.3 \%$, 344 명), 4-6명이 다음으로 많아( $25 \%, 143$ 명) 대체로 6명 이내의 아 동을 대상으로 문해중재를 실시한 것으로 나타났다. 또한 문해 중 재를 실시했던 영역을 묻는 질문에 음운인식, 읽기이해, 자모지식 과 글자지식, 단어수준의 읽기, 읽기 유창성, 철자쓰기, 작문쓰기 순 으로 응답하였으며 Table 5에 응답결과를 제시하였다.

한편 문해 중재가 필요함에도 불구하고 중재를 실시하지 못한 이 유를 묻는 질문에 대해 $63.9 \%$ (255명)가 '문해 중재보다 시급하게 중재할 영역이 있어서'라고 응답하였고, ‘중재에 대한 이론적 지식 의 부족'(147명, 36.8\%), '중재에 활용할 교재의 부족'(140명, 35.1\%), '중재 목표 설정의 어려움' $(119$ 명, $29.8 \%)$ 의 순으로 응답하였다.

\section{문해지식 및 문해 중재의 필요성에 대한 언어재활사의 인식} 학력 및 경력에 따른 문해지식, 문해 중재의 필요성에 대한 인식

학력 및 경력에 따라 문해지식 정도와 문해 중재의 필요성에 대 해 언어재활사의 인식을 알아보기 위해 카이검정을 실시한 결과 임 상경력에 따른 문해 중재의 필요성에 대한 인식 $\left(\chi^{2}=23.34, p>.05\right)$ 을 제외하고는 모두 유의한 차이가 있는 것으로 나타났다. 전문학 사와 학사의 경우 문해지식이 '보통’이라고 응답하는 비율이 가장 높았고, 석사수료 이상의 경우는 '그렇다'라고 응답하는 비율이 가 장 높았다. 임상경력에 따라서는 1년 미만에서 3-5년까지는 ‘보통’이 
라고 응답하는 비율이 높았으며, 5-10년과 10-20년은 ‘보통이다’와 '그렇다'의 비율이 비슷했다. 20 년 이상의 임상경력이 있는 경우는 '그렇다'는 응답률이 가장 높았다. 전체적으로 문해지식에 대한 인 식은 ‘보통이다'와 ‘그렇다’가 가장 많은 비율을 차지했는데, 학력이 높아질수록, 임상경력이 많아질수록 '그렇다'의 비율이 늘어나는 추세를 보여주었다. 이에 대한 결과를 Table 6에 제시하였다.

문해 중재가 중요하다고 생각하는가를 묻는 질문에 대해서는 임 상경험 기간과 상관없이 모두 44\%-68\% 이상의 응답자가 '매우 중 요하다'고 답하였다. 또한, 학력에 따른 문해지식 중재의 중요성에 대한 인식 정도를 살펴보면 전문학사의 경우만 '그렇다'의 비율이 $53.3 \%$, '매우 그렇다'의 비율이 $30.3 \%$ 로 나타났고, 나머지 학력구 간에서는 모두 '그렇다'(30.2\%-36.1\%)보다 '매우 그렇다' $(49.5 \%$ 66.7\%)라고 응답한 비율이 높게 나타났다. 이러한 결과는 학력이나 경력에 상관없이 대부분의 언어재활사들이 문해 중재를 매우 중요 한 언어재활사의 업무로 인식하고 있음을 알 수 있었다.

\section{교육 경험에 따른 문해지식, 문해 중재의 필요성에 대한 인식}

교육과정 중 문해관련 교과목을 이수했는지 여부와 문해교육연 수 경험 여부에 따라서 문해지식의 정도와 문해 중재의 필요성을 어떻게 인식하는지 알아보기 위해 카이검정을 실시한 결과 문해지 식 정도에 대한 인식은 교육과정을 통한 교과목 이수 여부 $\left(\chi^{2}=\right.$ $30.34, p<.05)$ 와 교육연수 등을 통한 교육 경험 유무 $\left(\chi^{2}=75.12\right.$, $p<.05)$ 에 따른 유의미한차이가 있었다(Table 7).

반면 교과목을 이수한 언어재활사는 평가 경험이 약 $70 \%$ 이상,

Table 6. Awareness about literacy knowledge according to degree and clinical career

\begin{tabular}{lccccc}
\hline & $\begin{array}{c}\text { Strongly } \\
\text { disagree }\end{array}$ & Disagree & Neutral & Agree & $\begin{array}{c}\text { Strongly } \\
\text { agree }\end{array}$ \\
\hline Degree & & & & & \\
Associate degree & $1(3.3)$ & $8(26.7)$ & $15(50)$ & $6(20)$ & $0(0)$ \\
Bachelor's degree & $10(3.1)$ & $72(22.6)$ & $127(39.8)$ & $85(26.6)$ & $25(7.8)$ \\
Master's diploma & $7(9.5)$ & $11(14.9)$ & $22(29.7)$ & $31(41.9)$ & $3(4.1)$ \\
Master's degree & $7(2.5)$ & $45(15.8)$ & $111(38.9)$ & $96(33.7)$ & $26(9.1)$ \\
Doctoral diploma & $0(0)$ & $3(14.3)$ & $3(14.3)$ & $10(47.6)$ & $5(23.8)$ \\
Doctoral degree & $0(0)$ & $3(10)$ & $7(23.3)$ & $12(40)$ & $8(26.7)$ \\
Clinical career (yr) & & & & & \\
$<1$ & $1(2.8)$ & $11(30.6)$ & $13(36.1)$ & $10(27.8)$ & $1(2.8)$ \\
$1-3$ & $5(3.3)$ & $34(22.7)$ & $56(37.3)$ & $44(29.3)$ & $11(7.3)$ \\
$3-5$ & $2(1.5)$ & $28(20.6)$ & $63(46.3)$ & $38(27.9)$ & $5(3.7)$ \\
$5-10$ & $12(5)$ & $46(19.1)$ & $89(36.9)$ & $73(30.3)$ & $21(8.7)$ \\
$10-20$ & $5(2.9)$ & $22(12.9)$ & $57(33.3)$ & $64(37.4)$ & $23(13.5)$ \\
$>20$ & $0(0)$ & $1(4)$ & $7(28)$ & $11(44)$ & $6(24)$ \\
\hline
\end{tabular}

Values are presented as number (\%).
중재 경험이 약 $85 \%$, 이수하지 않은 경우는 평가 경험이 약 $55 \%$, 중 재 경험이 약 $75 \%$ 로 나타났다. 교육연수 경험에 따라서는 연수를 받은 경우 평가 경험은 약 $73 \%$, 중재 경험은 약 $86 \%$ 이고, 받지 않은 경우 평가 경험은 약 $51 \%$, 중재 경험은 약 $74 \%$ 로 나타났다. 따라서 교과목 및 교육연수 등을 통해 교육 경험이 있는 언어재활사일수 록 평가 및 중재 경험이 더 높은 것으로 나타났으나 교육 경험이 없 는 언어재활사들이 평가 및 중재를 하게 되는 경우도 임상현장에 서는 다수 있는 것으로 보고되었다.

하지만 문해 중재의 필요성에 대한 인식은 교과목 이수 여부 $\left(\chi^{2}=\right.$ $6.0, p>.05)$ 나 교육연수 경험 유무 $\left(\chi^{2}=8.0, p>.05\right)$ 에 따라 유의한 차이가 없었다.

문해 사례 경험에 따른 문해지식, 문해 중재의 필요성에 대한 인식 문해 평가 및 중재가 필요한 사례를 본 경험이나 평가 또는 중재 경험 유무에 따른 문해지식 및 문해 중재 필요성에 대한 인식의 차 이를 알아보기 위해 카이검정을 실시한 결과 문해지식 정도는 문 해 사례를 본 경험의 유무 $\left(\chi^{2}=46.63, p<.05\right)$, 문해 평가 $\left(\chi^{2}=70.76\right.$, $p<.05)$ 및 문해 중재 $\left(\chi^{2}=47.23, p<.05\right)$ 를 실시해 본 경험 유무에 따라차이가 났다. 세 경험의 유형 모두 사례에 대한 경험이 있는 경 우, 스스로 전문적인 지식이 있다고 생각하는지를 묻는 문항에서 '보통이다', '그렇다'의 비율이 높았다. 반면, 사례에 대한 경험이 없 는 언어재활사의 경우 스스로 전문적인 지식이 있다고 생각하는지 를 묻는 문항에서 '그렇지 않다'와 '보통이다'의 비율이 높았다. 따 라서 사례를 본 경험이나 평가 및 중재에 대한 경험이 없는 언어재 활사의 경우는 문해지식이 부족하다고 인식하는 경향이 강했다. 한편 문해지식의 정도에 따라서 평가 및 중재 경험 유무를 살펴보 면 문해지식이 매우 없거나 없다고 답한 경우는 평가 경험이 없다 로 답한 비율이 높았으며, '보통이다'(60\%), '그렇다'(74.6\%), '매우 그렇다'(88.7\%)로 답한 경우 평가 경험이 있다고 응답한 비율이 높 았을 뿐 아니라 지식이 높다고 답할수록 평가 경험이 많은 것으로

Table 7. Awareness about literacy knowledge according to experience of literacy-related education

\begin{tabular}{lrllll}
\hline & $\begin{array}{c}\text { Strongly } \\
\text { disagree }\end{array}$ & Disagree & Neutral & Agree & $\begin{array}{c}\text { Strongly } \\
\text { agree }\end{array}$ \\
\hline $\begin{array}{l}\text { Curriculum at school } \\
\quad \text { Completion }\end{array}$ & $6(1.5)$ & $55(13.3)$ & $164(39.8)$ & $149(36.2)$ & $38(9.2)$ \\
Incompletion & $19(5.5)$ & $87(25.1)$ & $121(34.9)$ & $91(26.2)$ & $29(8.4)$ \\
Non-formal education & & & & & \\
$\quad$ Completion & $11(2.7)$ & $44(10.9)$ & $130(32.3)$ & $168(41.7)$ & $50(12.4)$ \\
Incompletion & $14(3.9)$ & $98(27.5)$ & $155(43.5)$ & $72(20.2)$ & $17(4.8)$ \\
\hline
\end{tabular}

Values are presented as number (\%). 
보고되었다. 또한 중재 경험과 관련해서 살펴보면 문해지식이 없다 고 답한 응답자의 경우만 중재 경험이 없다고 답한 비율이 높았는 데(58\%), ‘보통이다’ 이상의 지식 정도를 갖고 있다고 응답한 언어 재활사들의 중재 경험의 비율은 $82 \%-88 \%$ 사이로 유사하게 나타 나 평가 경험과 다른 패턴을 보여줬다.

또한 문해 중재 필요성에 대한 인식은 사례를 본 경험의 유무 $\left(\chi^{2}=\right.$ $38.02, p<.05)$ 나 평가를 한 경험의 유무 $\left(\chi^{2}=9.97, p<.05\right)$ 에 따라서 는 유의한차이가 있었으나중재 경험 유무에 따라서는 유의한차이 가 없는 것으로 나타났다 $\left(\chi^{2}=9.46, p>.05\right)$. 사례를 본 경험이 있는 경우와 평가를 한 경험이 있는 언어재활사의 경우 문해 중재가 필요 한가에 대해 '매우 그렇다', ‘그렇다’의 순서로 비율이 높았으나 이에 대한 경험이 없는 경우는 '그렇다', '매우 그렇다' 순서로 비율이 높 았다. 반면 중재를 한 경험 유무와 상관없이 문해 중재의 필요성에 대해서는 ‘매우 그렇다', ‘그렇다’의 순서로 비율이 높게 나타났다.

\section{문해교육의 필요성 및 문해교육 참가의지에 대한 언어재활사의 인식}

학력 및 경력에 따른 문해교육에 대한 인식

학력 및 경력에 따라 문해교육의 필요성을 느끼는지와 문해교육 이 있다면 참가할 의지가 있는지를 묻는 질문에 대해 학력이나 경 력에 따른 차이가 유의하지 않는 것으로 나타났다. 학력과 경력의 차이와 관련 없이 전체적으로 $95 \%$ 이상이 문해교육이 필요하다고 응답하였다. 또한 문해교육이 열린다면 참가할 의지가 있느냐는 질 문에 대해서도 모든 언어재활사들이 50\%-75\% 정도 매우 참가할 의지가 있다고 답하였다.

\section{교육 경험에 따른 문해교육에 대한 인식}

교육과정 중 문해관련 교과목을 이수했는지 여부와 문해교육연 수 경험 여부에 따라서 문해교육이 필요하다고 생각하는지와 문해 교육이 열린다면 참가한 의지가 있는지가 차이가 있는지 알아보기 위해 카이검정을 실시한 결과 모든 변인에서 유의한 차이가 나타나 지 않았다. 교과목 이수 여부 및 교육연수 경험과 상관없이 모든 언 어재활사는 약 $98 \%$ 정도가 문해교육이 필요하다고 응답하였다. 또 한 교과목 이수와 교육연수 경험 유무와 상관없이 $60 \%$ 이상의 언 어재활사들이 문해교육에 참가할 의지가 '매우 그렇다'라고 응답 하였다.

\section{문해 사례 경험에 따른 문해교육에 대한 인식}

문해 평가 및 중재가 필요한 사례를 본 경험이나 평가 또는 중재 경험 유무에 따라 문해교육의 필요성을 느끼는 정도에 차이가 있
는지 알아보기 위해 카이검정을 실시하였다. 그 결과 문해사례 경 험 유무와 상관없이 $98 \%$ 이상의 언어재활사들이 문해교육이 필요 하다고 응답하였다. 또한 문해교육이 열린다면 참가할 의지가 있는 지를 묻는 질문에 대해 사례 경험 유무에 따라 교육 참가 의지 정도 에 차이가 있었다 $\left(\chi^{2}=20.36, p<.05\right)$. 사례를 본 경험이 있는 $65.7 \%$ 의 언어재활사는 '매우 그렇다'라고 응답하였으나 경험이 없는 $47.2 \%$ 의 언어치료사가 ‘매우 그렇다', $35.8 \%$ 가 ‘그렇다'라고 응답하 였다. 하지만 평가 경험 유무나 중재 경험 유무에 따라서는 문해교 육에 참가할 의지 정도에는 차이가 없었다. 약 $65 \%$ 의 언어재활사가 평가 경험이나 중재 경험과 상관없이 참가할 의지가 매우 높다고 응답하였다.

\section{논의 및 결론}

본 연구는 언어재활사의 문해 평가 및 중재에 관한 인식, 요구도 및 경험을 대규모 설문연구를 통해 살펴보고 언어재활현장에서 문 해 평가 및 중재에 대한 어떠한 교육적 혹은 임상적인 요구가 있는 지를 살펴보고자 하였다. 본 연구를 통해 얻어진 결과를 논의하면 다음과 같다.

첫째, 본 연구의 결과로부터 현장에 있는 언어재활사 중 약 $90 \%$ (그렇다 $33.9 \%$, 매우 그렇다 $55 \%$ )의 언어재활사가 문해 능력 평가 및 중재에 대한 영역이 언어재활의 중요한 영역임을 인식하고 있음 에도 불구하고 이러한 영역에 대해 스스로 전문가적인 지식이 있다 고 응답한 비율은 약 $41 \%$ (그렇다 $31.7 \%$, 매우 그렇다 $8.9 \%$ )에 불과 한 것을 알 수 있었다. 이는 현장의 많은 언어재활사들이 문해 평가 및 중재와 관련하여 언어재활사로서의 책임감과 중요한 역할을 인 식하고 있음에도 불구하고, 이와 관련된 전문가로서의 지식과 정보 의 부족으로 어려움을 느끼고 있는 점이 반영된 결과라고도 할 수 있을 것이다. 이는 문해 능력 평가 및 중재를 위한 교육 프로그램의 제공이 매우 필요한 시점이라는 것을 시사한다. 그럼에도 불구하고 최근 협회나 학회에서 언어재활사들을 대상으로 한 다양한 문해교 육 프로그램을 제공하기 위한 노력을 하고 있다는 점과 본 연구결 과의 전반적인 내용을 살펴본다면 단순히 언어재활사 개인의 노력 이라는 차원에서는 이러한 어려움을 해소하는 데는 한계가 있을 것으로 여겨진다. 특히 문해 평가가 필요함에도 불구하고 평가를 실시하지 못한 경우의 이유를 묻는 문항에서 '진단 및 평가도구에 대한 지식의 부족(252명, $57.3 \%$ )'보다 높은 항목으로 나타난 것이 '진단 및 평가도구의 부재(253명, 46.1\%)'였다는 점에 비추어 생각 해 본다면, 언어재활사의 전문성의 증진을 위해서는 개인적인 차원 에서의 노력과 더불어, 장애 유형에 알맞은 다양한 검사도구가 갖 
추어진 환경이 뒷받침되어야 할 것이라는 시사점도 얻을 수 있다.

둘째, 문해 능력 평가 및 중재를 위해 필요하다고 생각하는 지식 이 어떠한 영역인지를 묻는 문항에서는 음운인식과 읽기이해가 가 장 높은 비율이었으며, 자모지식과 글자지식, 읽기 유창성, 어휘, 철 자쓰기 순으로 나타났다(Table 2). 음운인식이 대부분의 언어치료 사가 가장 중요하다고 생각하는 지식의 영역이라는 점은 국외 선행 연구와 일치하였으나(Katz et al., 2007), 쓰기 영역 대부분이 비교 적 높은 순위였던 국외 연구와는 달리 국내 연구에서는 철자쓰기 에 대한 중요도가 비교적 낮게 나타난 것을 확인할 수 있었다. 이와 같은 결과는 문해 중재 시 어떠한 영역에서의 중재를 실시하였는지 를 묻는 문항과도 비슷한 양상으로 나타났는데, 언어재활사가 음 운인식(577명, 76.2\%)을 가장 많이 지도한다고 응답하였으며, 읽기 이해, 자모지식과 글자지식, 단어수준 읽기, 읽기 유창성, 철자쓰기, 작문쓰기 순으로 응답하였다(Table 5). 이러한 중재 내용은 언어치 료사가 음운인식, 어휘, 문장 및 문단이해하기에 중점을 두고 읽기 중재를 실시한다고 한 Lee 등(2016)의 연구와 자폐스펙트럼장애 아 동을 대상으로 한 읽기 중재에서 읽기이해력이 가장 많은 비중을 차지했다고 보고한 Lee (2014)의 연구 등과 같이 음운인식과 읽기 이해를 언어재활사가 읽기 중재에서 중요하게 다루고 있다는 점에 서 유사하다. 또한 본 연구결과는 Katz 등(2007)이 미국 언어재활사 가 음운인식에 관한 지식을 가장 많이 갖고 있고, 철자쓰기 지식이 가장 적다고 보고한 연구결과와도 비슷한 양상으로 나타난 것을 알 수 있다. 이러한 결과는 음운 및 의미론을 중심으로 한 언어지식 기반 읽기 지도방식이 말언어 전문가인 언어재활사들에게 보다 친 숙하게 접근할 수 있는 방법이기 때문이라고 해석해 볼 수 있다. 한 편 읽기에 대한 직접적인 중재 외에도 음운인식 능력의 증진을 통 한 읽기 기술의 향상을 도모하는 언어재활사가 많은 것을 알 수 있 었다. 추후 한글의 읽기 및 쓰기 향상의 직접적인 향상에 어떠한 활 동이 효과적인지에 대해서도 추가적인 연구 등을 통해 살펴본다면 언어재활사의 효과적인 중재 활동에 도움이 될 것이라 생각한다.

셋째, 본 연구의 결과를 통해 문해 능력 평가 및 중재에 대한 언어 재활사들의 교육 요구도가 상당히 높은 것을 알 수 있었다. 본 연구 에 참여한 언어재활사 중 약 $98 \%$ 가 문해 평가 및 중재와 관련된 언 어재활사 교육이 필요하다고 응답하였으며, 문해 평가 및 중재와 관련된 전문가 교육에 대한 참여 희망에서 '매우 그렇다'(62.9\%)와 '그렇다'(28.3\%)의 응답비율이 $90 \%$ 이상인 것을 살펴볼 수 있었다. 특히 전문가 교육에서 다루기를 원하는 주제(중복 가능)가 문해 능력 평가의 실시 및 해석'(76.8\%), ‘치료의 실제와 임상사례 슈퍼비 전'(71.1\%), '치료 목표 설정'(61.6\%), '교재-교구 및 매체 활용'(56\%), '문해교육의 이론적 기초'(39.3\%) 순으로 높은 것을 알 수 있었는데
현장 언어재활사를 대상으로 설문을 실시한 만큼 실제 현장에서의 평가와 중재로 이어질 수 있는 교육내용을 희망하는 것을 알 수 있 었다. 또한 보기 중 비교적 낮은 비율이기는 하였으나, 문해교육의 이론적 기초에 대한 교육을 희망하는 언어재활사가 전체 중 $39 \%$ 이상이었다는 것 또한 주목할만한 결과라 할 수 있다. 본 연구결과 에서 대학 및 대학원에서 관련 교과목 이수를 한 언어재활사가 전 체의 절반가량(54.3\%)이라고 보고하였는데 이는 응답자의 약 $45 \%$ 는 정규교육과정을 통해 문해교육의 이론적 기초교육을 받은 경험 이 없다는 의미이기도 하다. 이들 언어재활사들 중에는 평가나 중 재에 대한 교육뿐 아니라 문해교육의 이론적 기초 지식을 요구하고 있다고추정해 볼수 있다.

넷째, 다수의 언어재활사들은 임상현장에서 문해 평가 및 중재 가 필요한 사례를 본 경험이 있었고, 사례를 본 언어재활사가 실제 평가 및 중재를 실시한 경우도 다수를 차지하는 것으로 나타났다. 응답자의 $83.9 \%$ (655명)가 사례를 본 경험이 있다고 응답하였고, 경 험이 있다고 응답한 언어재활사 중에 $63.7 \%$ (410명)가 문해 평가를 실시하였으며, 중재를 실시한 경험이 있다고 응답한 언어재활사는 $80.8 \%$ (525명)이었다. 이는 실제 임상현장에서 상당수의 언어치료 사가 문해 평가 및 중재가 필요한 아동 사례를 만나고 있으므로 문 해 평가 및 중재와 관련된 지식과 교육의 필요성이 높다는 의미로 해석해 볼 수 있다. 이는 다수의 언어재활사들이 읽기 중재에 대한 애플리케이션 콘텐츠 개발의 요구가 높다는 연구(Lee et al., 2016) 와 초등교사를 대상으로 의사소통 문제를 겪는 아동들이 국어를 가장 어려워하고 읽기 및 쓰기 문제가 언어이해 및 표현 문제 다음 으로 어려움을 겪는다고 보고하면서 읽기 및 쓰기를 지도하는 것 이 언어재활사의 업무로 인식한다고 보고한 Park (2013)의 연구를 지지해 주는 결과이다. 언어재활 서비스가 바우처사업이나 교육청 사업 등으로 확대되면서 학령기 이후에도 지속적으로 서비스가 연 장되는 경우가 많아지게 된 점도 문해지원 아동 증가에 영향을 미 쳤을 것이다(Lee et al., 2016). 이는 다수의 언어재활사가 구어뿐 아 니라 문어에 대한 지원 요구가 있는 학령기 아동 사례를 경험하고 있기 때문에 언어재활사들에게 좀 더 체계적인 문해 지원이 필요함 을 시사해 주고 있다. 또한 본 연구결과는 미국의 경우 $60.3 \%$ 의 언 어재활사가 매주 또는 매일 읽기 및 쓰기장애 아동들에게 서비스 를 제공하고 있으며(Blood et al., 2010), 학교 언어재활사가 서비스 를 제공하고 있는 사례 $63 \%$ 가 학습문제가 있고, 그중 $32 \%$ 가 읽기 및 쓰기장애 아동이라고 보고한 선행연구 결과와도 유사하다 (ASHA, 2008). 미국의 선행연구의 경우 학교 언어재활사를 대상으 로 한 것이어서 본 연구와 단순 비교하는 것은 제한이 있지만 본 연 구에서 실제 757 명 중 평가 경험이 있는 언어재활사는 $54 \%$ (410명), 
중재 경험은 $69 \%$ (525명)로 보았을 때 임상현장에서 문해지원이 필 요한 아동을 만나는 언어재활사의 비율이 미국의 경우와 큰 차이 가 없는 것을 알 수 있다.

하지만 언어재활사들이 본 사례 중에 약 $40 \%$ 정도는 평가를 실 시하지 못하고, 약 $20 \%$ 는 중재를 실시하지 못하고 있는 것으로 나 타나 문해지원이 필요한 사례를 현장에서 본 경험이 있음에도 불 구하고 문해 평가 및 중재로 이어지지 못하는 경우도 적지 않게 있 었다. 본 연구결과에 의하면 설문에 참여한 언어재활사 중에서 문 해 평가 실시 경험이 있다고 응답한 경우가 $63.7 \%$ (410명)이었으나 문해 중재를 실시했는지를 묻는 질문에 대해서는 $80.8 \%$ (525명)가 있다고 대답하였다. 이러한 결과에 비추어 볼 때 실제 약 $20 \%$ 는 평 가 절차 없이 중재 지원이 이루어지는 것으로 추정해 볼 수 있다. Katz 등(2007)에 의하면 미국의 언어재활사도 문해지원이 필요한 아동의 $33 \%$ 가 서비스를 제공받지 못하는 것으로 보고하고 있어 실 제적 지원의 어려움이 있다. 특히 본 연구결과에서는 중재에 비해 평가로 이어지는 사례가 더 비율이 낮았는데 평가로 이어지지 못하 는 이유에 대한 질문에 약 $50 \%$ 가량의 언어재활사가 '진단 및 평가 도구의 부재'와 '진단 평가방법에 대한 지식부족'을 지적하였다. 이 는 실제 임상현장에서 문해지원이 필요한 아동을 평가할 검사도구 가 부족할 뿐 아니라 최근 개발된 몇몇 검사도구도 치료실에 구비 되어 있지 않은 치료실이 많아 문해지원환경의 시급한 개선이 필요 함을 시사해 주고 있다. 또한 검사를 실시하고 그 결과를 해석할 전 문지식에 대한 교육이 시급하게 필요함을 알 수 있다. 한편 중재로 이어지지 못하는 이유를 묻는 질문에 대해 '문해 중재보다 시급하 게 중재할 영역이 있어서'가 다수였고, 중재에 대한 지식부족, 활용 교재의 부족, 중재목표 선정의 어려움 순서로 응답하였다. $\mathrm{Na}$ 와 Oh (2018)는 중도장애 학생의 초기 문해학습을 위해 보완대체의 사소통 체계를 적용하기 어려운 이유로 부모의 부정적 견행, 도구 부족, 학습자료 부족, 치료사 지식 부족이 높게 나타났다고 하여 지 식 부족과 활용 교재의 문제에 대한 공통된 요구가 있음을 보여주 고 있다.

다섯째, 언어재활사들은 학력 및 경력이 높을수록, 교과목을 이 수하거나 문해교육연수 경험이 있을수록, 문해관련 사례 경험이 있는 경우일수록 문해지식의 정도가 높다고 인식하고 있었다. 또한 교육 경험이 있는 언어재활사가 평가 및 중재를 더 많이 경험하였 고, 문해지식이 높다고 답할수록 평가 경험이 많았다. '문해지식이 없다’고 답한 경우 ‘중재 경험이 없다'고 답한 비율은 $58 \%$ 정도 나 타났으나 ‘보통 이상으로 있다’고 답한 경우는 모두 $80 \%$ 이상의 언 어재활사가 중재 경험이 있다고 응답하였다. 이러한 연구결과는 미 국 언어재활사를 대상으로 조사한 Katz 등(2007)의 연구에서 문해
지식이 높다고 인식할수록 문해지원 서비스에 대해 더 긍정적인 태 도를 갖고 있어 정적 상관관계가 있음을 보고한 것과 유사하다. 하 지만 교과목 수강 이력에 따라서 중재 경험 차이가 나지 않았다고 한 Lee (2003)의 연구와는 다르게 나타났다. 이는 자폐범주성 아동 을 대상으로 중재를 실시하는 언어재활사에 한정된 연구여서 본 연구의 설문대상과는 차이가 있기 때문인 것으로 해석된다. 그런데 여기서 주목해 봐야 할 것은 문해관련 교육 경험이 있는 언어재활 사가 평가 및 중재를 더 많이 경험하기는 했어도 문해관련 교육 경 험이 없는 언어재활사가 평가를 실시한 경우는 약 $51 \%-55 \%$, 중재 를 실시한 경우는 약 74\%-75\%로 조사되었으며, 문해지식이 '전혀 없다'고 응답한 언어재활사들 중 평가 경험이 있다고 응답한 경우 는 약 $7 \%$, 문해지식이 '없다'고 인식하는 언어재활사 중에서는 약 $41 \%$ 가 평가 경험이 있다고 응답하였다. 또한 중재 경험의 경우 문 해지식이 '매우 없는' 언어재활사의 약 $2 \%$, '없다'고 인식한 언어재 활사의 약 $62 \%$ 가 중재를 실시한 경험이 있는 것으로 나타났다는 점이다. 이 결과는 임상현장에서 스스로 문해지식이 매우 없다고 느끼고 있음에도 임상현장에서는 실제 평가나 중재가 이루어지고 있어 무엇보다 문해 평가 및 중재와 관련된 교육 요구가 매우 높을 것으로 사료되며 언어재활사들에게 문해교육 관련 교육체계가 시 급히 마련될 필요가 있음을 시사해 준다. 한편, 문해 평가 및 중재가 언어치료의 중요한 영역인가를 묻는 질문에 대해서는 학력, 경력, 교육 경험 여부와 상관없이 '매우 그렇다'라고 응답한 언어재활사 의 비율이 가장 높았다. 문해 중재 경험이 있는 언어재활사들 역시 문해 평가 및 중재가 언어치료에 매우 중요한 영역이라고 응답한 경 우가 많았다. 반면에 사례를 본 경험이나 평가 경험이 없는 언어재 활사의 경우 '그렇다'로 응답한 비율이 '매우 그렇다'에 비해 다소 높은 응답률을 보였다. 하지만 전체적으로 볼 때 대부분의 언어재 활사들이 문해 평가 및 중재가 언어치료의 주요 영역이라고 인식하 는 것으로 나타났다.

여섯째, 대부분의 언어재활사들은 학력, 경력, 교육이나 사례 경 험 여부와 상관없이 언어재활사들을 위한 '문해교육이 매우 필요 하다'고 답한 경우가 가장 높을 뿐 아니라 그 응답률도 $95 \%-98 \%$ 에 달해 임상현장에서 문해교육에 대한 요구가 매우 높은 것으로 나 타났다. 이는 임상현장에 근무하는 다수의 언어재활사가 문해관련 전문교육을 통해서 지식을 습득해야 한다고 인식하고 있다고 해석 해 볼 수 있다. 반면 문해관련 교육이 열리면 참가할 의지가 있느냐 는 질문에 대해서 다수의 언어재활사가 참가의지가 있다고 응답하 였지만 응답률은 약 $50 \%-75 \%$ 정도로 문해교육이 필요하다고 인식 하는 비율에 비해 다소 낮게 나타났다. 교육에 대한 참가 의지는 학 력, 경력, 평가나 중재경험 유무와 상관없이 유사한 비율로 '그렇다' 
와 ‘매우 그렇다’에 응답하였다. 하지만 사례를 본 경험의 유무에 따 라서는 참가 의지가 '매우 높다'고 응답한 비율에 차이가 있었다. 언 어재활사의 특성에 따라 참가 의지가 다르게 나타나는지를 좀 더 자세히 분석해 보니 문해지식이 '매우 있다'고 답한 언어재활사가 교육에 참가하겠다는 의지도 가장 높게 나타났고(76.1\%), 문해지식 이 '매우 없다', '없다', '보통이다', '있다'로 응답한 언어재활사들 모 두 약 $60 \%$ 의 비율로 문해교육 참가 의지가 '매우 있다'라고 응답하 여 문해지식에 대한 인식 여부와 상관없이 문해교육에 대한 요구가 높음을 알 수 있었다. 또한 문해 중재가 '중요하거나' '매우 중요하 다'고 답한 언어재활사가 문해교육에 참가할 의지도 유의하게 높게 나타났는데 ‘중요하다'고 응답한 경우 약 $44 \%$, '매우 중요하다'고 한 언어재활사들은 약 $83 \%$ 가 교육에 참가하겠다는 의지가 매우 높 았다. 이런 결과는 미국 언어재활사를 대상으로 연구한 Katz 등 (2007)의 연구에서 다수의 응답자가 문해 서비스 제공에 대한 지식 과 태도도 좋고 문해 서비스를 제공하기 위해 더 학습할 의지가 있 다고 보고한 것과 유사하다. 다만 우리나라 언어재활사의 경우 문 해지식에 대해 더 많이 이해하고 있고, 더 필요하다고 느낄수록 실 제 교육에 참여하겠다는 의지가 더 높다는 점에 주목해 볼 필요가 있다.

최근 기초학력부진 아동에 대한 관심이 증가하고 있는 시점에서 기초학력과 밀접한 관련이 있는 문해 능력을 적극적으로 지원해 줄 전문인력의 필요성이 강조되고 있다. 이러한 시점에서 언어재활사 는 문해 능력 지원을 위한 전문인력의 일원으로서 주요한 역할을 담당해야한다. 이에 본 연구결과는 문해교육지원 전문인으로서 현 재 언어재활사들의 인식과 요구를 파악함으로써 임상현장에서 적 용할 수 있는 실질적인 교육의 필요성을 제기하고 요구되는 교육내 용에 대한 시사점을 제공해 주었다는 점에서 의의가 있다. 문해교 육전문가로서 언어재활사의 전문역량을 강화하기 위해서는 언어 재활사를 양성하는 교육과정에서뿐 아니라 언어재활사들의 임상 역량을 강화할 수 있는 교육내용에 이르기까지 폭넓게 고민되어야 할 것이다.

\section{REFERENCES}

Ahn, S. W. (2005). A comparison of two reading intervention programs for children with reading disabilities. Journal of Speech \& Hearing Disorders, 14(1), 105-125.

American Speech-Language-Hearing Association. (2008). 2008 Schools Survey: caseload characteristics report. Rockville, $\mathrm{MD}$ : Author.

Blood, G. W., Mamett, C., Gordon, R., \& Blood, I. M. (2010). Written lan- fuage disorders: speech-language pathologist's training, knowledge, and confidence. Language, Speech, and Hearing Services in Schools, 41(4), 416-428.

Choi, Y. J., Kim, Y. T., Yun, H. R., \& Sung, J. E. (2011). Spelling ability of the final consonants in children with reading disabilities. Korean Journal of Communication \& Disorders, 16(2), 154-170.

Chung, B. J. (2011). Relationships among word recognition, reading comprehension, phonological awareness, working memory, listening comprehension, and inferential skills: a two-year longitudinal study of second and third graders. Journal of Speech \& Hearing Disorders, 20(1), 103-121.

Chung, B. J. (2014). The characteristics of mazes in story and expository retelling by poor readers. Journal of Speech \& Hearing Disorders, 23(1), 171-189.

Craig, H. K., Connor, C. M., \& Washington, J. A. (2003). Early positive predictors of later reading comprehension for African American students. Language, Speech, and Hearing Services in Schools, 34(1), 31-43.

Hallahan, D. P., Lloyd, J. W., Kauffman, J. M., Weiss, M. P., \& Martinez, E. A. (2005). Learning disabilities: foundations, characteristics, and effective teaching (3rd ed.). Boston, MA: Person.

Kamhi, A. G., Allen, M. M., \& Catts, H. W. (2001). The role of the speechlanguage pathologist in improving decoding skills. Seminars in Speech and Language, 22(3), 175-184.

Kang, K. H., \& Hwang, B. M. (2010). A study on language ability, reading abilities and phonological awareness abilities for 5 years old children from multicultural families and general families. Journal of Speech-Language \& Hearing Disorders, 19(1), 143-158.

Katz, L. A., Fallon, K. A., Blenkarn, K., Smith, M., John, J., Olszewski, K., \& Maag, A. (2007). Written language \& the school-based speech-language pathologist: a national survey. Presented at the 2007 ASHA Convention, Boston, MA.

Kersting, F., Carr, C., \& Kersting, J. (2008). Speech-language pathologists' role perception in teaching literacy: process and content. Presented at the 2008 ASHA Convention, Chicago, IL.

Kim, A., Kim U., Hwang, M., \& Yoo, H. (2014). Test of Reading Achievement and Reading Cognitive Processes Ability. Seoul: Hakjisa.

Kim, A. H., \& Kang, E. Y. (2010). A comparison of word recognition skills between elementary students with reading disabilities and students without disabilities: focusing on word recognition performance and error patterns. Korean Journal of Communication \& Disorders, 15(4), 632-647.

Kim, A. H., Park, S. H., \& Kim, J. H. (2010). Reading fluency of elementary 
students in Korea: Reading developmental patterns and error patterns. Korean Journal of Communication \& Disorders, 15(1), 43-55.

Kim, M. K., Yoon, C. Y., \& Ahn, S. W. (2003). A study of investigating double deficit hypothesis for children with reading disabilities in Korea. Journal of Speech \& Hearing Disorders, 12(2), 241-254.

Korea Institute for Curriculum and Evaluation. (2014). Guidelines for management of 'Do-dream' school. http://www.basics.re.kr/boardCnts/view. do?boardID=149\&boardSeq=1006726\&lev=0\&m=060204\&searchType= null\&statusYN=W\&page=2\&s=kucu.

Korea Ministry of Education. (2013). Practical plan of national issue in 2013. https://moe.go.kr/boardCnts/view.do?boardID=294\&boardSeq=42817\&l ev=0\&searchType $=$ null\&statusYN=W\&page $=245 \& s=$ moe $\& \mathrm{~m}=0503 \&$ op Type $=\mathrm{N}$.

Lee, M. K. (2014). Status and perception on reading intervention for students with autism spectrum disorders: focused on speech language pathologists. Journal of Speech \& Hearing Disorders, 23(3), 113-128.

Lee, M. L., \& Lee, H. R. (2014). Characteristics of the spoken expository discourse of 3-4 grade school-aged children with language learning disabilities. Communication Sciences \& Disorders, 19(4), 456-466.

Lee, W. R. (2003). The effects on phonological awareness, naming speed, and reading ability of children with reading disabilities through phonological awareness training. Journal of Speech \& Hearing Disorders, 12(2), 61-80.

Lee, Y., Kim, Y. T., \& Park, E. H. (2016). Analysis on current practice and needs based survey of parents and speech-language pathologists for reading intervention with smart device applications. Communication Sciences
\& Disorders, 21(3), 502-514.

Na, J. Y., \& Oh, G. A. (2018). Clinicians' and teachers' perception and need concerning language learning and literacy education of students with severe communication disorders. AAC Research \& Practice, 6(1), 1-22.

Navas, A. L., Ciboto, T., \& Borges, J. P. A. (2017). Reading disorders and the role of speech-language pathologists. In F. Fernandes (Ed.), Advances in speech-language Pathology (pp. 99-107). London: InTech Open.

Pae, S., \& Kim, M. (2010). Language based reading abilities of Korean schoolaged children with multicultural backgrounds. Korean Journal of Communication Disorders, 15(2), 146-156.

Pae, S., Kim, M., Yoon, H. J., \& Jang, S. (2015). Korean Language Based Reading Assessment (KOLRA). Seoul: Hakjisa.

Pae, S. Y., Kim, M. B., \& Jung, K. H. (2012). Grammatical morphemes of school-aged Korean children with or without poor reading. Journal of Speech \& Hearing Disorders, 21(1), 17-37.

Park, B. R., \& Choi, Y. L. (2014). The relationship among visual perception ability, phonological awareness ability and reading ability in 4- to 5-yearold children. Journal of Speech \& Hearing Disorders, 23(3), 91-103.

Park, J. H. (2013). The perception of elementary school teachers about communication disorders and speech and language therapy for school aged children (Master's thesis). Daegu University, Gyeongsan, Korea.

Yoo, J. Y. (2013). A study of the reading abilities of preschool children from multicultural families. Journal of Speech \& Hearing Disorders, 22(3), 133-146. 


\section{국문초록}

\section{문해 평가 및 중재에 관한 언어재활사의 인식, 요구도 및 경험에 대한 설문 연구 \\ 박현린 ${ }^{1}$ 정경희 ${ }^{2} \cdot$ 배소영 ${ }^{3}$ 윤효진 ${ }^{4}$ \\ 1광주대학교 보건복지교육대학 언어치료학과, ${ }^{2}$ 용인대학교 재활복지대학원 언어치료학과, ${ }^{3}$ 한림대학교 언어청각학부, ${ }^{4}$ 조선대학교 언어치료학과}

배경 및 목적: 본 연구는 문해 평가 및 중재에 관한 언어재활사의 인식, 요구도 및 경험에 대한 설문조사를 통하여 언어재활현장에서의 문해 평가 및 중재 현황을 살펴보고 더불어 어떠한 교육적인 요구가 있는지를 살펴보고자 하였다. 방법: 언어재활사협회 회원으로 등 록된 언어재활사 중 설문에 응답한 757명을 연구대상으로 하였다. 설문은 응답자 기본정보, 문해관련 지식 및 교육 경험, 문해 평가 및 중재에 대한 필요성 인식과 교육 요구도, 문해 평가 및 중재 경험으로 구성되었다. 결과: 현장 언어재활사들 중 약 $90 \%$ 가 문해 평가 및 중 재가 언어재활의 중요한 영역임을 인식하고 있음에도 불구하고 전문가로서의 지식이 있다고 응답한 비율은 약 $40 \%$ 에 불과하였다. 또한 전체 중 $90 \%$ 이상이 관련 교육 참여를 희망한다고 응답하였다. 대다수의 언어재활사들은 임상현장에서 문해 평가 및 중재가 필요한 사 례를 본 경험이 있으나, 문해 평가로 이어진 경우는 이들 중 $64 \%$ 가량이었다. 언어재활사들은 학력과 경력이 높을수록 문해지식의 정도 가 높다고 인식하였으며, 문해관련 교육 경험과 사례 경험이 있을 경우 그렇지 않은 경우에 비해 문해지식의 정도가 높다고 인식하고 있 었다. 한편 대부분의 언어재활사들은 학력, 경력, 교육이나 사례 경험 여부와 상관없이 문해교육이 매우 필요하다고 답한 경우가 상당 히 높아(95\%-98\%) 임상현장에서의 높은 요구를 살펴볼 수 있었다. 논의 및 결론: 본 연구 결과로부터 추후 관련 교육의 확대 및 환경적 개선이 이루어지기를 기대해 본다.

핵심어: 문해 평가, 문해 중재, 언어재활사

본 논문은 한국언어재활사협회의 ‘2018년 역량강화사업’ 용역과제로 시행된 연구임.

\section{참고문헌}

강금화, 황보명(2010). 5세 다문화가정 아동과 일반가정 아동의 언어, 읽기, 음운인식능력에 관한 연구. 언어치료연구, 19(1), 143-158.

교육부(2013). 2013년 국정과제 실천계획. https://moe.go.kr/boardCnts/view.do?boardID $=294 \& b o a r d S e q=42817 \& l e v=0 \& s e a r c h T y p e=$ null\&sta tusYN $=$ W\&page $=245 \& s=$ moe\&m $=0503 \&$ opType $=\mathrm{N}$

김미경, 윤치연, 안성우(2003). 한글 읽기장애 아동의 음운인식 능력과 명명속도 결손에 관한 비교 연구. 언어치료연구, 12(2), 241-254.

김애화, 강은영(2010). 초등학교 읽기장애 학생과 일반 학생의 단어인지 특성 비교연구: 단어인지 수행력 및 오류 패턴 비교. 언어청각장애연구, 15(4), 632-647.

김애화, 김의정, 황민아, 유현실(2014). 읽기성취 및 읽기인지처리 능력 검사(RA-RCP). 서울: 학지사.

김애화, 박성희, 김주현(2010). 초등학생의 읽기유창성 특성 연구: 읽기유창성 발달 패턴 및오류 유형 분석. 언어청각장애연구, 15(1), 43-55.

나지영, 오경아(2018). 중도장애학생의 언어 학습 및 문해교육에 대한 치료사와 특수교사의 인식 및 요구 연구. 보완대체의사소통연구, 6(1), 1-22.

박보라, 최예린(2014). 4-5세 일반 아동의 초기 읽기 능력과 시지각 및 음운인식 능력 간 관련성. 언어치료연구, 23(3), 91-103.

박진희(2013). 학령기 의사소통장애 및 언어치료에 대한 초등학교 교사들의 인식. 대구대학교 대학원 석사학위논문.

배소영, 김미배(2010). 초등 저학년 다문화가정 아동의 읽기와 언어. Communication Science Disorders, 15(2), 146-156.

배소영, 김미배, 윤효진, 장승민(2015). 한국어 읽기 검사(KOLRA). 서울: 학지사.

배소영, 김미배, 정경희(2012). 읽기부진 아동의 문법형태소 사용력. 언어치료연구, 21(1), 17-37.

안성우(2005). 읽기 장애 아동의 읽기 능력 향상을 위한 PREP 와 음운 인식 훈련 프로그램의 효과 비교. 언어치료연구, 14(1), 105-125.

유재연(2013). 학령전기 다문화 가정 아동의 읽기능력 특성. 언어치료연구, 22(3), 133-146.

이미경(2014). 자폐스펙트럼장애 학생의 읽기 중재 실태 및 인식: 언어재활사를 중심으로. 언어치료연구, 23(3), 113-128. 
이미림, 이희란(2014). 설명담화 유형에 따른 초등학교 3-4 학년 언어학습장애아동의 말하기 특성. Communication Sciences \& Disorders, 19(4), 456-466.

이영미, 김영태, 박은혜(2016). 읽기 중재 어플리케이션 개발을 위한 장애 아동의 읽기중재 실태 및 부모, 언어치료사의 요구 분석. Communication

Sciences \& Disorders, 21(3), 502-514.

이원령(2003). 음운인식훈련이 읽기장애아동의 음운인식, 명명속도, 읽기에 미치는 효과. 언어치료연구, 12(2), 61-80.

정부자(2011). 초등학교 저학년 읽기부진아동의 읽기능력 및 읽기관련변인에 대한 종단연구. 언어치료연구, 20(1), 103-121.

정부자(2014). 이야기와 설명문 다시 말하기 과제에 나타난 일반아동과 읽기부진아동의 비유창성 (mazes) 특성. 언어치료연구, 23(1), 171-189.

최윤정, 김영태, 윤혜련, 성지은(2011). 낱말 친숙도 및 음운규칙 적용 유무에 따른 학령기 읽기장애 아동의 받침철자 인식 및 쓰기 특성. 언어청각장

애연구, 16(2), 154-170.

한국교육과정평가원(2014). 두드림학교 운영가이드: 한 아이를 키우려면 온 학교가 필요합니다. http://www.basics.re.kr/boardCnts/view.do?boardI

$\mathrm{D}=149$ \&boardSeq $=1006726 \& \mathrm{lev}=0 \& \mathrm{~m}=060204 \&$ searchType $=$ null\&statusYN $=$ W\&page $=2 \& \mathrm{~s}=\mathrm{kucu}$

\section{ORCID}

박현린(https://orcid.org/0000-0002-5250-6893); 정경희(https://orcid.org/0000-0002-1816-0171);

배소영(https://orcid.org/0000-0001-6577-0880); 윤효진(https://orcid.org/0000-0003-0011-2566) 